Universal Decimal Classification (UDC) number 613.2: 613.9 (470.325)

\title{
HUMAN HEALTH RISK ASSESSMENT OF THE CHEMICAL CONTAMINATION OF FOOD PRODUCTS AND RAW FOODS
}

\author{
V.V. Fetter \\ Belgorod Region Department of the Federal Service on Customers' Rights Protection and Human Well-Being \\ Surveillance, Russian Federation, Belgorod, 2 Zheleznyakova St., 308023, \\ Federal State Autonomous Educational Institution of Higher Professional Education "Belgorod State National \\ Research University", Russian Federation, Belgorod, 85 Pobedy St., 308015
}

\begin{abstract}
The results of assessment of health risk posed to children and adult population of the Belgorod region due to consumption of food contaminated with chemicals are shown. Priority contaminants and their concentrations in foods are identified. Contribution of the studied contaminants and food groups in the formation of population exposure levels is determined. The development of non-carcinogenic effects determined by combined effect of food contaminants is characterized, and organs and systems mostly affected by toxic exposure are defined. Calculations of individual and population carcinogenic risk resulting from consumption of chemically contaminated foods are performed.

Key words: chemical contaminants, population exposure, contribution, non-carcinogenic risk, critical organs and systems of the human body, carcinogenic risk.
\end{abstract}

Establishment and functioning of the Customs Union, the entry of the Russian Federation in $\mathrm{WTO}^{1}$ and in $\mathrm{OECD}^{2}$ requires bringing all applicable national sanitary requirements for food safety in line with international standards developed based on the methodology of public health risk assessment and management. Therefore, the development and application in practice of territorial bodies and agencies of the Federal Service for Consumer Rights Protection and Human Welfare, of the methods for assessment of risk imposed by chemical contaminants contained in food is of particular relevance and will facilitate training of specialists to work effectively under conditions of harmonization of national and foreign principles of introduction of food safety norms.

Wide spreading nature of chemical pollutants, their accumulation in plants and animals directly from the environment or through the so-called food chains, causes chemical contamination of raw foods, food products and delivery of the most dangerous to human health xenobiotics into human body with food through the gastrointestinal tract [1, 4].

The data provided reflect the results of the studies from 2011-2012, which were focused

(C) Fetter V.V., 2013

Fetter, Vladimir Vilmarovich - PhD, Deputy Head, Docent of the Department of Medical and Preventive Disciplines, the Institute of Medicine (e-mail: Orgotd@31.rospotrebnadzor.ru, tel.: 8 (4722) 34-30-27).

\footnotetext{
${ }^{1}$ WTO - World Trade Organization

${ }^{2}$ OECD - Organization for Economic Cooperation and Development.
} 
on health-related assessment of content of chemical substances of foreign origin ${ }^{3}$ in foods in the Belgorod region and on assessment of human health risk on the basis of the data obtained.

At the first stage of the work, the data of laboratory investigations of food raw materials and food products were studied, which were carried out in 2005-2009 by the Federal StateFunded Healthcare Institution "Centre for hygiene and epidemiology in the Belgorod region" and which formed a database of the Regional Information Foundation for Social and Health monitoring (RIF SHM).

Excesses of regulatory levels of foreign substances of chemical origin were determined in 555 samples $(0.8 \%)$ of the tested food products. The most contaminated were horticultural products, which accounted for 90.1\% (500 samples) of the total number of contaminated products. Priority contaminants of horticultural products were nitrates, which contributed 97.2 $\%$ of the total pollution, while the average long-term exceed factor of the maximum permissible levels in 2005-2009 reached 3.5 [6].

The above studies have identified the trends of a time-, area- and species-related distribution of nitrate pollution of horticultural products in the Belgorod region. However, the results obtained did not allow a quantitative assessment of the role of nitrate pollution of horticultural products in the morbidity in the population.

To solve this problem, a second phase of the study was stared, the aim of which was to assess the health risk to the population of the region imposed by exposure to chemical contaminants in food products.

A distinctive feature of the methodology of public health risk assessment, which makes it possible to analyse the exposure to any defined concentration of substances hazardous to human health, including those that do not exceed the national maximum permissible levels [2, $3,5]$, contributed to a significant expansion of the research area and defined materials and methods of this research.

Taking into account the data on per capita food product consumption ${ }^{4}$ for $2005-2010$ the list of foods for assessment of levels of contaminants incoming with food intake, except horticultural products (fruits, berries, vegetables, melons) additionally included all major groups (bread, meat, dairy and fish products, vegetable oil and other fats, sugar and confectionery).

\footnotetext{
${ }^{3}$ Materials of the studies were published in: Ocenka himicheskoj kontaminacii pishhevyh produktov [Assessment of chemical contamination of food products]//Sanitarnyj vrach. [ Sanitary doctor]/article in Russian/. 2011. Number 9.

${ }^{4}$ For the study the data on per capita food consumption were used, provided by the territorial body of the Federal State Statistics Service in the Belgorod region (Belgorodstat).
} 
In total, 60,096 results of food product tests were analysed (Table 1), which were performed by laboratories of the Federal State-Funded Healthcare Institution "Centre for hygiene and epidemiology in the Belgorod region" in 2005-2010 and included in Regional Information Foundation for Social and Health monitoring.

The parameters necessary for health risk assessment were calculated for two subpopulations - children (0-6 years) and adults (18 and older). Processing of source data ${ }^{5}$, determination of contaminant content, exposure calculation and interpretation of the results obtained were carried out in accordance with the recommendations of the Federal Service for Consumer Rights Protection and Human Welfare (Rospotrebnadzor) ${ }^{6}$.

As the criteria for assessment of public health risk posed by the tested chemical substances, the formally recommended data on the reference (safe) concentrations by chronic exposures affecting critical organs and systems of the human body, the mean daily maximum allowable concentrations established by the direct toxic effects on health, etc., were used [2, 3 , $5]$.

Table 1

\section{Information on the number of laboratory tests used for assessment of health public risk in the area for 2005-2010}

\begin{tabular}{|l|c|c|c|c|c|c|c|}
\hline \multicolumn{1}{|c|}{ Product groups investigated } & 2005 & 2006 & 2007 & 2008 & 2009 & 2010 & Total \\
\hline Horticultural products & 1825 & 2828 & 4029 & 2768 & 3883 & 1970 & 17303 \\
\hline Bread and bakery products & 1471 & 1148 & 1085 & 902 & 998 & 1012 & 6616 \\
\hline Milk and dairy products & 1998 & 1781 & 1655 & 1838 & 1867 & 1442 & 10581 \\
\hline Meat & 978 & 887 & 1281 & 1412 & 1203 & 852 & 6613 \\
\hline Fish and fish products & 237 & 177 & 315 & 250 & 112 & 117 & 1208 \\
\hline Vegetable oil and other fats & 1249 & 942 & 1473 & 1900 & 1521 & 1267 & 8352 \\
\hline Sugar confectionery & 2134 & 1520 & 1989 & 1726 & 1207 & 847 & 9423 \\
\hline Total & 9892 & 9283 & 11827 & 10796 & 10791 & 7507 & 60096 \\
\hline
\end{tabular}

Results and discussion. The initial stage of the study included identification and selection of the priority, indicatory chemicals contained in food products, investigation of which allows characterization of levels of public health risk with sufficient reliability.

The main criteria for identification and selection of chemical contaminants were: the availability of information on concentrations of contaminants in food product; possibility for entering of contaminants in food products from different contaminated environmental objects

\footnotetext{
5 The processing of the database "Contamination of food raw materials and food products by chemical substances" of the Regional Information Foundation for Social and Health Monitoring, including statistical analysis of materials, was carried out by specialists of the Social and Health Monitoring Department of the Directorate of he Federal Service for Consumer Rights Protection and Human Welfare (Rospotrebnadzor) in the Belgorod region, under supervision of the author.

${ }^{6}$ Guidelines R 2.1.10.1920-04. Guidelines for assessment of public health risk posed by exposure to chemical substances polluting the environment; Methodological instructive regulations MU 2.3.7.2519-09. Determination of exposure and assessment of risk of the population exposure to chemical contaminants of food products.
} 
(ambient air, water, soil), the data on the effects on human health; the use of contaminants in crop farming as pesticides or mineral fertilizers; lifetime of chemical substances and their compounds in the environment; toxicity; potential for bioaccumulation, etc.

Using the above criteria the following substances were included in the list of chemicals selected for the study: cadmium (Cd), arsenic (As), mercury (Hg), lead ( $\mathrm{Pb})$, hexachlorocyclohexane $(\mathrm{HCH})$, dichlorodiphenyltrichloroethane (DDT) and nitrates.

In order to improve the reliability of the data, calculation of the content (concentration) of the studied pollutants and their exposure were conducted by centile trends based on an average dose of distribution of the concentration of toxic substances in the investigated products $\left(\mathrm{C}_{\text {mean }}\right)$, and the upper bound of exposure based on the 90th percentile $\left(\mathrm{C}_{90}\right)$ of this distribution (Tables 2 , $3)$.

The conducted studies on the above mentioned food product groups have established that the greatest contribution to the population exposure (Exp) to cadmium, arsenic, mercury, lead (Table 4) is made by: milk and dairy products (43.9, 26.1, 46.6 and 39.1\%, respectively); potatoes $^{7}(19.7,20.0,15.0$ and $17.5 \%$, respectively), as well as meat and meat products (17.6, 21.6, 25.8 and $22.5 \%$, respectively).

Exposure to nitrates is determined by vegetables and melons $(66.3 \%)$ as well as potatoes (33.7\%). Contribution to the exposure made by hexachlorocyclohexane $(\mathrm{HCH})$ and dichlorodiphenyltrichloroethane (DDT) is also entirely provided by vegetables and melons.

Based on localization of harmful changes in the human body (Table 5), cadmium, arsenic, mercury, lead, hexachlorocyclohexane $(\mathrm{HCH})$, dichlorodiphenyltrichloroethane (DDT) and nitrates are referred to systemic toxicants. When performing a conservative assessment of the combined non-carcinogenic action of the above-mentioned contaminants, simultaneously entering the body with food products, most likely is that the type of their effect on the same organs and systems is additive $[3,5]$.

Characterization of risk of non-carcinogenic effects was based on comparing the values of contaminant exposure (Exp), obtained during studies with safe (reference) levels $\left(R f C_{\mathrm{O}}\right)$ of their exposure and calculations of hazard coefficients $(H Q)$.

\footnotetext{
${ }^{7}$ Potatoes are included in a separate group due to the large volume of consumption by the population.
} 
Table 2

Cadmium, arsenic, mercury and lead contents in food products in 2005-2010

\begin{tabular}{|c|c|c|c|c|c|c|}
\hline \multirow{2}{*}{ Chemical substance } & \multicolumn{5}{|c|}{ Distribution of average annual concentrations of chemical substances (mg/kg) } \\
\cline { 3 - 7 } & Fy product groups \\
\cline { 3 - 7 } \multicolumn{2}{|c|}{ Fruits, berries } & $\begin{array}{c}\text { Vegetables, } \\
\text { melons }\end{array}$ & Potatoes & $\begin{array}{c}\text { Milk and diary } \\
\text { products }\end{array}$ & $\begin{array}{c}\text { Meat and meat } \\
\text { products }\end{array}$ \\
\hline \multirow{2}{*}{ Cadmium } & Cmean & $8,35 \mathrm{E}-04$ & $6,01 \mathrm{E}-03$ & $6,85 \mathrm{E}-03$ & $3,41 \mathrm{E}-03$ & $5,35 \mathrm{E}-03$ \\
\cline { 2 - 7 } & C90 & $6,13 \mathrm{E}-03$ & $1,49 \mathrm{E}-02$ & $2,02 \mathrm{E}-02$ & $1,21 \mathrm{E}-02$ & $1,67 \mathrm{E}-02$ \\
\hline \multirow{2}{*}{ Arsenic } & Cmean & $5,26 \mathrm{E}-03$ & $3,07 \mathrm{E}-02$ & $8,21 \mathrm{E}-03$ & $3,41 \mathrm{E}-03$ & $3,75 \mathrm{E}-02$ \\
\cline { 2 - 7 } & C90 & $6,50 \mathrm{E}-02$ & $7,29 \mathrm{E}-02$ & $8,00 \mathrm{E}-02$ & $2,81 \mathrm{E}-02$ & $8,00 \mathrm{E}-02$ \\
\hline \multirow{2}{*}{ Mercury } & Cmean & - & $1,85 \mathrm{E}-03$ & $6,94 \mathrm{E}-04$ & $4,03 \mathrm{E}-03$ & $5,64 \mathrm{E}-03$ \\
\cline { 2 - 7 } & C90 & - & $4,67 \mathrm{E}-03$ & $6,00 \mathrm{E}-03$ & $5,00 \mathrm{E}-03$ & $9,50 \mathrm{E}-03$ \\
\hline \multirow{2}{*}{ Lead } & Cmean & $2,05 \mathrm{E}-02$ & $4,28 \mathrm{E}-02$ & $3,35 \mathrm{E}-02$ & $2,62 \mathrm{E}-02$ & $5,86 \mathrm{E}-02$ \\
\cline { 2 - 7 } & C90 & $8,40 \mathrm{E}-02$ & $1,06 \mathrm{E}-01$ & $1,50 \mathrm{E}-01$ & $9,03 \mathrm{E}-02$ & $1,78 \mathrm{E}-01$ \\
\hline
\end{tabular}

Note: Cmean - contaminant concentrations calculated with the account of the mean dose of centile trends; $\mathrm{C}_{90}-$ contaminant concentrations calculated with the account of the 90th percentile.

Table 3

Food product content $\left(\mathrm{Cmean}, \mathrm{C}_{90}\right)$ of hexachlorocyclohexane $(\mathrm{HCH})$, dichlorodiphenyltrichloroethane (DDT) and nitrates in 2005-2010

\begin{tabular}{|c|c|c|c|c|c|c|}
\hline \multirow{3}{*}{ Product group } & \multicolumn{6}{|c|}{ Average annual concentrations (mg/kg) } \\
\cline { 2 - 7 } & $\begin{array}{c}\text { Hexachlorocyclohexane } \\
(\mathrm{HCH})\end{array}$ & $\begin{array}{c}\text { Dichlorodiphenyltrichloro } \\
\text { ethane (DDT) }\end{array}$ & \multicolumn{2}{c|}{ Nitrates } \\
\cline { 2 - 7 } & Cmean & C90 & Cmean & C90 & Cmean & C90 \\
\hline Vegetables, melons & $5,15 \mathrm{E}-03$ & $1,38 \mathrm{E}-02$ & $9,92 \mathrm{E}-04$ & $5,95 \mathrm{E}-03$ & $2,22 \mathrm{E}+02$ & $4,28 \mathrm{E}+02$ \\
\hline Potatoes & - & - & - & - & $1,23 \mathrm{E}+02$ & $2,11 \mathrm{E}+02$ \\
\hline
\end{tabular}

Indicators of exposure resulting from intake of

Table 4 $\mathrm{Cd}, \mathrm{As}, \mathrm{Hg}$ and Pb with food products in 2005-2010 (mg/kg/day)

\begin{tabular}{|c|c|c|c|c|c|c|c|c|c|}
\hline \multirow{2}{*}{\multicolumn{2}{|c|}{ Product group }} & \multicolumn{2}{|c|}{ Cadmium } & \multicolumn{2}{|c|}{ Arsenic } & \multicolumn{2}{|c|}{ Mercury } & \multicolumn{2}{|c|}{ Lead } \\
\hline & & Adults & Children & dults & Children & Adults & Children & Adults & Chil \\
\hline \multirow{2}{*}{ ruits, } & $\operatorname{Exp}_{\mathrm{cp}}$ & $1,0 \mathrm{E}-06$ & & $6,9 \mathrm{E}-06$ & $3,2 \mathrm{E}-05$ & 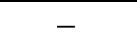 & 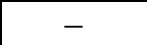 & $2,4 \mathrm{E}-05$ & $1,1 \mathrm{E}-04$ \\
\hline & & $8,1 \mathrm{E}-06$ & & ,5E-05 & 2,6 & $\begin{array}{l}- \\
-\end{array}$ & - & -04 & -04 \\
\hline \multirow{2}{*}{$\begin{array}{l}\text { Vegetables, } \\
\text { melons }\end{array}$} & & 6 & 1,2 & $2 \mathrm{E}-05$ & 5,5 & $7,0 \mathrm{E}-07$ & E-06 & 05 & 05 \\
\hline & & & & 5 & 94 & 6 & & & \\
\hline \multirow{2}{*}{ tato } & & & & 2,3 & 1,1 & 6 & & & \\
\hline & & & & 2,21 & 1,01 & & & & \\
\hline \multirow{2}{*}{$\begin{array}{l}\text { Milk and milk } \\
\text { products }\end{array}$} & & 06 & 6, & $1,4 \mathrm{E}-05$ & $7,4 \mathrm{E}-06$ & $8,2 \mathrm{E}-07$ & 06 & 05 & -05 \\
\hline & & & & $1,4 \mathrm{E}-05$ & $6,7 \mathrm{E}-05$ & $1,1 \mathrm{E}-06$ & 5,3E-06 & 05 & ,4E-04 \\
\hline \multirow{2}{*}{$\begin{array}{l}\text { Meat and } \\
\text { meat products }\end{array}$} & & -05 & 7,2E-05 & $1,1 \mathrm{E}-04$ & $5,1 \mathrm{E}-04$ & $1,7 \mathrm{E}-05$ & $8,2 \mathrm{E}-05$ & $1,8 \mathrm{E}-04$ & $8,4 \mathrm{E}-04$ \\
\hline & $\operatorname{Exp} 90$ & 5,2E-05 & 2,3E-04 & 2,3E-04 & $1,1 \mathrm{E}-03$ & $2,9 \mathrm{E}-05$ & 1,3E-04 & $5,5 \mathrm{E}-04$ & $2,6 \mathrm{E}-03$ \\
\hline
\end{tabular}

Note: Expcp and Exp90 - exposures calculated with the account of the mean concentration (Cmean) nd the 90th percentile (C90) of contaminant content in food products. 


\section{Information on parameters of hazard of non-carcinogenic effects of chemical contaminants horticultural products}

\begin{tabular}{|c|c|c|c|c|c|c|c|c|c|}
\hline \multirow{2}{*}{ Substance } & CAS & $R_{f} f \mathrm{O}^{8}, \mathrm{mg} / \mathrm{kg}$ & \multicolumn{7}{|c|}{ Affected organs and systems } \\
\hline Cadmium & $7440-43-9$ & 0,0005 & Kidneys & Hormon. & & & & & \\
\hline Arsenic & $7440-38-2$ & 0,0003 & & Hormon. & CNS & PNS & CVS & & \\
\hline Mercury & $7439-97-6$ & 0,0003 & Kidneys & Hormon. & CNS & & & & \\
\hline Lead & $7439-92-1$ & 0,0035 & & Hormon. & CNS & PNS & & & Blood \\
\hline HCH & $58-89-9$ & 0,0003 & Kidneys & & & & & Liver & \\
\hline DDT & $50-29-3$ & 0,00175 & & Hormon. & & & & Liver & \\
\hline Nitrates & $14797-55-8$ & 1,6 & & & & & CVS & & Blood \\
\hline
\end{tabular}

Note: CAS - international identification code of the substance; Hormon. - neuroendocrine system; CNS - central nervous system; PNS - peripheral nervous system, CVS - cardiovascular system [3, 5].

Detailed analysis of the average annual hazard coefficients $(H Q)$ revealed a number of values $(>1.0)$ indicating an increased level of non-carcinogenic risk. Thus, in the population of children $\mathrm{HQ}_{\text {mean }}{ }^{9}$ values for nitrates which came with vegetables and melons in 2005-2010 were 2.08-4.25, with potatoes in 2006 and $2007-2.21$ and 1.48, respectively, and with fruits and berries in 2005 3.74 .

Maximum values of $H Q_{90}{ }^{10}$ for the child population, as determined by nitrates, lead and arsenic are shown in Table 6. For the adult population increased content of contaminants in food at the 90th percentile were determined by nitrates contained in vegetables and melons in 2006-2010. (HQ90 within the range 1.03-1.96).

In other cases, the $H Q$ values for contaminants in the studied groups of food products consumed by child and adult populations in 2005-2010, calculated from the mean centile trend $\left(H Q_{\text {mean }}\right)$ and at the upper bound of the 90th confidence interval $(H Q 90)$, did not exceed 1.0.

In case of simultaneous intake of several contaminants by the same route (orally with food), characterization of risk of non-carcinogenic effects was made on the basis of the hazard index $(H I)$ calculation [3].

Maximum values of $H I$ for the whole period analysed (2005-2010) calculated for adults and children from $H Q_{\text {mean }}$ and $H Q_{90}$ (Table 7), are observed for vegetables and melons, followed by milk and dairy products, and then - meat and meat products.

The main contribution both in the total $H I$ of investigated food product groups (Table 8), and in the risk of non-cancer diseases is made by arsenic, lead and nitrates.

\footnotetext{
${ }^{8} \mathrm{RfCo}$-reference concentration of the chemical substance, the lifelong daily exposure by chronic oral intake, not causing any unacceptable health risk in sensitive populations.

${ }^{9} \mathrm{HQmean}$ - hazard coefficient- measure of the risk of non-carcinogenic effects, calculated by Expcp.

${ }^{10}$ HQ90 - coefficient hazard - measure of the risk of non-carcinogenic effects, calculated by Exp90.
} 
The chemical contaminants studied $(\mathrm{Cd}, \mathrm{As}, \mathrm{Hg}, \mathrm{Pb}$, hexachlorocyclohexane $(\mathrm{HCH})$, dichlorodiphenyltrichloroethane (DDT) and nitrates, found in the analysed food product groups during 2005-2010. (Table 9), have the potential to induce a variety of adverse effects in the body [3].

Table 6

Hazard coefficients $\left(\mathrm{HQ}_{90}\right)$ of food products contaminated by nitrates, lead and arsenic calculated for child population

\begin{tabular}{|c|l|c|c|}
\hline \multirow{2}{*}{ Contaminant } & \multicolumn{1}{|c|}{ Product group } & $\begin{array}{c}\text { Calculation period, } \\
\text { years }\end{array}$ & $H Q_{90}$ value \\
\hline \multirow{2}{*}{ Nitrates } & Potatoes & $2007-2010$ & $1,82-5,94$ \\
\cline { 2 - 4 } & Vegetables, melons & $2005-2010$ & $1,27-9,17$ \\
\hline \multirow{3}{*}{ Lead } & Potatoes & 2005 & 1,66 \\
\cline { 2 - 4 } & Milk and milk products & $2006-2010$ & $1,26-2,65$ \\
\cline { 2 - 4 } & Meat and meat products & $2008-2010$ & $1,10-1,26$ \\
\hline \multirow{3}{*}{ Arsenic } & Vegetables, melons & 2008 & 1,77 \\
\cline { 2 - 4 } & Milk and milk products & 2008 & 1,26 \\
\cline { 2 - 4 } & Meat and meat products & $2006 ; 2009$ & 3,$2 ;, 10$ \\
\hline
\end{tabular}

Table 7

Total hazard indexes $(H I)$ for different food product groups for 2005-2010

\begin{tabular}{|c|c|c|c|c|c|c|c|c|c|c|c|}
\hline \multicolumn{2}{|c|}{ Year, subpopulation } & \multicolumn{2}{|c|}{ Fruit, berrie } & \multicolumn{2}{|c|}{$\begin{array}{l}\text { Vegetables } \\
\text { and melons }\end{array}$} & \multicolumn{2}{|c|}{ Potatoes } & \multicolumn{2}{|c|}{$\begin{array}{c}\text { Milk } \\
\text { and milk } \\
\text { products }\end{array}$} & \multicolumn{2}{|c|}{$\begin{array}{l}\text { Meat and meat } \\
\text { products }\end{array}$} \\
\hline & & $H I_{\text {mea }}$ & $H I 90$ & $H I_{\text {mea }}$ & $H I 90$ & $H I_{\text {mea }}$ & HI90 & $H I_{\text {mea }}$ & HI90 & $H I_{\text {mea }}$ & $H I 90$ \\
\hline \multirow{2}{*}{2005} & lits & 0.07 & 0.23 & 2.26 & 3.46 & 0.52 & 0.87 & 0.59 & 2.62 & 0.34 & 1.21 \\
\hline & Children & 0.29 & 1.23 & 10.74 & 16.17 & 2.43 & 4.07 & 2.77 & 13.91 & 6.49 & 5.64 \\
\hline \multirow{2}{*}{2006} & Adults & 0.14 & 1.41 & 1.80 & 3.02 & 2.10 & 7.02 & 0.91 & 3.39 & 2.07 & 5.85 \\
\hline & Chil & 0.58 & 6.58 & 2.56 & 14.12 & 9.80 & 32.78 & 4.11 & 15.83 & 9.66 & 27.28 \\
\hline \multirow{2}{*}{2007} & Adults & - & - & 1.97 & 4.44 & 0.87 & 2.45 & 1.17 & 4.05 & 0.07 & 0.11 \\
\hline & Chil & - & - & 9.18 & 20.89 & 4.04 & 12.10 & 5.44 & 19.25 & 0.34 & 0.77 \\
\hline \multirow{2}{*}{2008} & Adults & 0.26 & 2.77 & 2.47 & 7.37 & 0.84 & 6.26 & 0.90 & 3.49 & 4.72 & 8.92 \\
\hline & Children & 1.24 & 12.91 & 11.54 & 34.38 & 1.96 & 29.22 & 4.19 & 16.31 & 22.03 & 41.60 \\
\hline \multirow{2}{*}{2009} & Adults & 0.09 & 0.38 & 1.68 & 4.18 & 0.73 & 1.84 & 1.13 & 3.81 & 0.47 & 1.37 \\
\hline & Children & 0.41 & 1.76 & 7.83 & 19.52 & 3.36 & 8.61 & 5.28 & 17.79 & 2.21 & 6.40 \\
\hline \multirow{2}{*}{2010} & Adults & 0.03 & 0.16 & 1.54 & 3.14 & 0.66 & 1.67 & 1.31 & 4.01 & 0.59 & 1.72 \\
\hline & Children & 0.16 & 0.76 & 5.77 & 14.68 & 2.97 & 7.81 & 2.92 & 18.71 & 2.75 & 8.04 \\
\hline
\end{tabular}

Note: $H I_{\text {mean }}$ - hazard index calculated by $H Q_{\text {mean }} ; H I_{90}$ - hazard index calculated by $H Q_{90}$. 


\section{Contribution of chemical contaminants from food products in non-carcinogenic risk for a population}

\begin{tabular}{|c|c|c|c|c|c|c|c|}
\hline \multirow{3}{*}{ Contaminant } & \multirow{2}{*}{ Product } & \multicolumn{5}{|c|}{ Contribution of contaminants in $H I(\%)$} \\
\cline { 2 - 8 } & & 2005 & 2006 & 2007 & 2008 & 2009 & 2010 \\
\hline \multirow{3}{*}{ Arsenic } & Fruits, berries & - & 83.10 & - & 91.98 & - & - \\
\cline { 2 - 8 } & Potatoes & - & 55.71 & - & 59.41 & - & - \\
\cline { 2 - 8 } & Meat and meat products & - & 71.97 & - & 70.31 & - & - \\
\hline \multirow{3}{*}{ Lead } & Fruits, berries & 100.0 & - & - & - & 86.37 & 79.45 \\
\cline { 2 - 8 } & $\begin{array}{c}\text { Milk and milk } \\
\text { products }\end{array}$ & 90.80 & - & 95.72 & - & 97.76 & 93.48 \\
\cline { 2 - 8 } & Meat and meat products & 86.95 & - & - & - & 93.96 & 89.32 \\
\hline \multirow{2}{*}{ Nitrates } & Vegetables u melons & - & 69.51 & 90.30 & - & 76.19 & 80.54 \\
\cline { 2 - 8 } & Potatoes & - & - & 54.24 & - & 50.14 & 55.87 \\
\hline
\end{tabular}

In addition, the data obtained suggest that the systems most susceptible to adverse effects of mixtures of the studied food product toxicants include the following: hematopoietic (20.60$23.30 \%)$, cardiovascular (17.25-17.77 \%) and neuroendocrine system (11.47-11.67\%). The maximum risk for these systems and organs is posed by the exposure to arsenic, lead and nitrates contained in foods consumed in the region (Table 9).

Probability of the potential damage to other critical organs and systems of the body (immune, reproductive, peripheral nervous and central nervous systems, biochemical values, gastrointestinal tract, skin, liver, kidneys), resulting from special characteristics of unidirectional exposure to contaminants contained in food were as follows: for adults - from 1.04 to $8.63 \%$ for children - from 1.19 to $9.19 \%$.

Most (5 of 7) of the contaminants selected for further studies $(\mathrm{Cd}, \mathrm{As}, \mathrm{Pb}$, hexachlorocyclohexane $(\mathrm{HCH})$ and dichlorodiphenyltrichloroethane (DDT)), presented in Table 10 are potential chemical carcinogens of Groups $1,2 \mathrm{~A}$ and $2 \mathrm{~B}$ according to the IARC $^{11}$ classification or of Groups A, B1 and B2 according to the US EPA ${ }^{12}$ classification [4, 5].

Information on the results of calculations of individual (ICR) and population (PCR) carcinogenic risk to public health posed by food contamination with cadmium, arsenic, lead, hexachlorocyclohexane $(\mathrm{HCH})$ and dichlorodiphenyltrichloroethane (DDT), are presented in Tables 11 and 12 .

\section{Conclusions:}

1. The largest contribution to the exposure of the population to cadmium, arsenic, mercury and lead ingested with food products is made by milk and dairy products, potatoes, and

\footnotetext{
${ }^{11}$ IARC- International Agency for Research on Cancer

${ }^{12}$ US EPA -U.S. Environmental Protection Agency.
} 
meat and meat products. Exposure of the population to nitrates, hexachlorocyclohexane $(\mathrm{HCH})$ and dichlorodiphenyltrichloroethane (DDT) is determined by the consumption of vegetables, melons and potatoes.

2. Assessment of hazard coefficients $(H Q)$ for nitrates, lead and arsenic contained in horticultural products demonstrated the presence of alarming non-carcinogenic risk for children's health $\left(H Q_{\text {mean }} 1.48-4.25 ; H Q_{90} 1.10-9.17\right)$, and the content of nitrates in vegetables and melons, calculated from the 90th percentile demonstrated an acceptable level of non-carcinogenic risk for adult population of the region $\left(H Q_{90} 1.03-1.96\right) .20 .60 \pm 2.63$

Table 9

\section{Contribution of neuroendocrine, hematopoietic and cardiovascular systems of the body in the risk of general toxic effects under exposure to food contaminants of unidirectional action}

\begin{tabular}{|c|c|c|c|c|c|c|c|}
\hline \multirow{2}{*}{$\begin{array}{l}\text { Critical organs and } \\
\text { systems }\end{array}$} & \multirow{2}{*}{$\begin{array}{l}\text { Contaminants } \\
\text { determining } \\
\text { the exposure }\end{array}$} & \multicolumn{2}{|c|}{$\begin{array}{c}\text { Contribution of food } \\
\text { products to hazard index } \\
(\mathrm{HI}),(\%)\end{array}$} & \multicolumn{2}{|c|}{ Student's t-value } & \multicolumn{2}{|c|}{$\begin{array}{c}\text { Statistical } \\
\text { significance }(p)\end{array}$} \\
\hline & & Adults & Children & Adults & Children & Adults & Children \\
\hline $\begin{array}{l}\text { Neuroendocrine } \\
\text { system }\end{array}$ & $\begin{array}{l}\text { As, Pb, Cd, } \\
\mathrm{Hg}, \mathrm{DDT}\end{array}$ & $11.47 \pm 2.84$ & $11.67 \pm 2.74$ & 4.02 & 4.26 & $<0.002$ & $<0.002$ \\
\hline $\begin{array}{c}\text { Hematopoietic system } \\
\text { and peripheral blood } \\
\text { values }\end{array}$ & $\mathrm{Pb}$, Nitrates & $20.60 \pm 2.63$ & $23.30 \pm 2.62$ & 7.83 & 8.88 & $<0.0001$ & $<0.0001$ \\
\hline $\begin{array}{c}\text { Haematopoietic } \\
\text { system }\end{array}$ & As, Nitrates & $17.25 \pm 2.56$ & $17.77 \pm 2.53$ & 6.74 & 7.01 & $<0.0001$ & $<0.0001$ \\
\hline
\end{tabular}

\section{Information on the indicators of risk of carcinogenic effects of chemical} contaminants from horticultural products

\begin{tabular}{|l|c|c|c|c|}
\hline \multirow{2}{*}{ Substance } & \multirow{2}{*}{ CAS } & \multicolumn{3}{c|}{ Oral intake } \\
\cline { 3 - 5 } & & IARC & EPA & $S F_{0}$ \\
\hline Cadmium & $7440-43-9$ & 1 & B1 & 0,38 \\
\hline Arsenic & $7440-38-2$ & 1 & A & 1,5 \\
\hline Lead & $7439-92-1$ & $2 \mathrm{~A}$ & B2 & 0,047 \\
\hline Hexachlorocyclohexane (HCH) & $58-89-9$ & 3 & B2 & 1,3 \\
\hline Dichlorodiphenyltrichloroethane (DDT) & $50-29-3$ & 2B & B2 & 0,34 \\
\hline
\end{tabular}

Note : $S F_{\mathrm{o}}-$ carcinogenic potential factor for the oral route of entry, $(\mathrm{mg} /(\mathrm{kg} \cdot \text { day }))^{-1}$ 
Indicators of carcinogenic risk to public health imposed by contamination of food products with chemical substances in 2005-2010

\begin{tabular}{|c|c|c|c|c|c|c|c|}
\hline \multirow{2}{*}{ Substance } & \multirow{2}{*}{$\begin{array}{l}\text { Slope } \\
\text { factor } \\
\left(S F_{\mathrm{O}}\right)\end{array}$} & \multicolumn{3}{|c|}{ Mean centile trend } & \multicolumn{3}{|c|}{90 -th percentile } \\
\hline & & Exptotal & $I C R$ & $P C R$ & Exptotal & $I C R$ & $P C R$ \\
\hline Cadmium & 0,380 & $4,00 \mathrm{E}-05$ &, $52 \mathrm{E}-05$ & 19 & $1,15 \mathrm{E}-04$ & $4,38 \mathrm{E}-05$ & 55 \\
\hline Lead & 0,047 & $3,30 \mathrm{E}-04$ &, $55 \mathrm{E}-05$ & 19 & $1,16 \mathrm{E}-03$ & $5,45 \mathrm{E}-05$ & 68 \\
\hline Hexachlorocyclohexane $(\mathrm{HCH})$ & 1,300 & $3,38 \mathrm{E}-06$ & 1,39E-06 & 6 & 7,94E-06 & $1,03 \mathrm{E}-05$ & 13 \\
\hline $\begin{array}{l}\text { Dichlorodiphenyltrichloroethane } \\
\text { (DDT) }\end{array}$ & 0,340 & $3,54 \mathrm{E}-07$ & ,20E-07 & 0,2 & $1,77 \mathrm{E}-06$ & $6,01 \mathrm{E}-07$ & 1 \\
\hline
\end{tabular}

Note : $\operatorname{Exp}_{\text {total }}$ - total exposure; ICR - individual cancer risk to human health;

$P C R$ - population cancer risk to public health.

Table 12

\section{Indicators of carcinogenic risk to public health imposed by contamination of food products with arsenic in 2005-2010}

\begin{tabular}{|l|c|c|c|c|c|}
\hline \multirow{2}{*}{ Localization of cancer } & \multirow{2}{*}{ Slope factor (SFo) } & \multicolumn{2}{|c|}{ Mean centile trend } & \multicolumn{2}{c|}{90 -th percentile } \\
\cline { 3 - 6 } & & $I C R A s$ & PCRAs & ICRAs & PCRAs \\
\hline Liver & 1,00 & $1,66 \mathrm{E}-04$ & 208 & $5,81 \mathrm{E}-04$ & 729 \\
\hline Lungs & 2,50 & $4,14 \mathrm{E}-04$ & 520 & $1,45 \mathrm{E}-03$ & 1823 \\
\hline Bladder & 2,50 & $4,14 \mathrm{E}-04$ & 520 & $1,45 \mathrm{E}-03$ & 1823 \\
\hline Kidneys & 0,86 & $1,43 \mathrm{E}-04$ & 179 & $5,00 \mathrm{E}-04$ & 627 \\
\hline Lather & 1,50 & $2,49 \mathrm{E}-04$ & 312 & $8,71 \mathrm{E}-04$ & 1094 \\
\hline Cancer of any type of location & & $1,39 \mathrm{E}-03$ & 1740 & $4,86 \mathrm{E}-03$ & 6097 \\
\hline
\end{tabular}

Note : $I C R_{\mathrm{As}} P C R_{\mathrm{As}}$ - individual and population cancer risks to human health, resulting from food product contamination with arsenic.

3. Assessment of hazard indexes $(H I)$ has shown that the main contribution to the development of non-carcinogenic risk in the population exposed to chemically contaminated food, was made by lead (79,45-100,0\%), arsenic (55,71-91,98\%) and nitrates $(50,14-90,30 \%)$.

4. If lead, arsenic and nitrates simultaneously enter the human body, the critical systems exposed to the greatest toxic effects are hematopoietic (20.60-23.30\%), cardiovascular (17.25-17.77 $\%$ ) and neuroendocrine systems.

5. Individual cancer risk (ICR), resulting from dichlorodiphenyltrichloroethane (DDT) content in food products, is estimated as negligibly small, it does not require additional measures for reduction of this risk and is subject to periodic selective control.

6. The individual cancer risk (ICR) value determined by the content of cadmium, lead and hexachlorocyclohexane $(\mathrm{HCH})$ in food products ranges from $4.39 \mathrm{E}-06$ to $5.45 \mathrm{E}-05$ that corresponds to the maximum permissible risk, i.e. the upper boundary of acceptable risk. These levels of individual cancer risk in the population are subject to continuous monitoring.

7. Total individual cancer risk (ICR) determined by the content of arsenic in food 
products is $4.86 \mathrm{E}-03$, and for certain types of localizations this risk is within the range from $8.71 \mathrm{E}-04$ to $1.45 \mathrm{E}-03$ that corresponds to the third range of classification of risk levels and is acceptable for professional groups, but unacceptable for the population of the region in general.

This level of risk requires the development and planning of health-improving measures. Planning of measures for risk reduction in this case should be based on in-depth assessment of all stages of production, processing, storage, distribution and consumption of food products.

8. The value of the population cancer risk (PCR) determined by the content of cadmium, lead and hexachlorocyclohexane $(\mathrm{HCH})$ in food products, suggests the likelihood of the occurrence in the population of the region of 13 to 68 additional (to the background level of cancer incidence) cases of malignant tumours.

9. The highest levels of the population risk are determined in connection with the exposure to arsenic contained in food products consumed by the population of the region.

The value of this risk amounts to 729 to 1823 additional cases of cancer of different localization, and totally for all types of cancer localization this value approaches 6097 cases, additionally to the background rates of cancer incidence.

\section{References}

1. Docenko V.A. Jekologo-gigienicheskaja koncepcija pitanijac heloveka [Ecological and environmental health concept of human diet]. Gigiena i sanitarija, 1990, no. 7, pp. 13-18.

2. Opredelenie jekspozicii i ocenka riska vozdejstvija himicheskih kontaminantov pishhevyh produktov na naselenie: metodicheskie ukazanija [The determination of exposure and health risk assessment of human exposure to chemical contaminants in food products: methodical guidelines]. Moscow: Federal'nyj Centrgigieny i jepidemiologii Rospotrebnadzora, 2009. $26 \mathrm{p}$.

3. Onishhenko G.G., Novikov S.M., Rahmanin Ju.A., Avaliani S.L., Bushtueva K.A. Osnovy ocenki riska dlja zdorov'ja naselenija pri vozdejstvii himicheskih veshhestv, zagrjaznjajushhih okruzhajushhuju sredu [Basics of health risk assessment of exposure to chemical substances polluting the environment]. Ed. Ju.A. Rahmanina, G.G. Onishhenko. Moscow: NII JeCh i GOS, 2002.408 p.

4. Kuz'min S.V., Kacnel'son B.A., Privalova L.I., Gurvich V.B., s soavt. Principy i metodicheskie podhody $\mathrm{k}$ ocenke himicheskoj jekspozicii naselenija $\mathrm{s}$ produktami pitanija [Principles and methodical approaches to the assessment of chemical exposure of the population via food products]. Ocenka $i$ upravlenieriskom dlja zdorov'ja naselenija: sb. informmetoddokumentov, Ekaterinburg, 2009, pp. 201-323.

5. Rukovodstvo po ocenke riska dlja zdorov'ja naselenija pri vozdejstvii himicheskih veshhestv, zagrjaznjajushhihokruzhajushhujusredu [Guidelines for health risk assessment of exposure to chemical substances polluting the environment]. Moscow: Federal'nyj centr Gossanjepidnadzora Minzdrava Rossii, 2004. 143 p.

6. Fetter V.V., Berdinskih N.N., Zav'jalova N.A. Ocenka sostojanija himicheskoj kontaminacii pishhevyh produktov [An assessment of the condition of chemical contamination of food products]. Sanitarnyjvrach, Moscow: Medizdat, 2011, no. 9. pp. 20-23. 